\title{
Development, information and social connectivity in Côte d'Ivoire
}

\author{
Clio Andris ${ }^{*}$ and Luis MA Bettencourt
}

\begin{abstract}
Understanding human socioeconomic development has proven to be one of the most difficult and persistent problems in science and policy. Traditional policy has often attempted to promote human development through infrastructure and the delivery of services, but the link between these engineered systems and the complexity of human socioeconomic behavior remains poorly understood. Recent research suggests that the key to socioeconomic progress lies in the development of processes whereby new information is created by individuals and organizations and embedded in the structure of social networks at a diverse set of scales, from nations to cities to firms. Here, we formalize these ideas in terms of network theory - namely the spatial network of mobile phone communications in Côte d'Ivoire-to show how incipient socioeconomic connectivity may constitute a general obstacle to development. Inspired by recent progress in the theory of cities as complex systems, we then propose a set of tests for these theories using telecommunications network data and describe how telecommunication services may generally help promote socioeconomic development.
\end{abstract}

Keywords: Economic development; Mobile phone networks; Complex systems; Côte d'Ivoire; Urban infrastructure; Telecommunications; Geography; Africa

PACS numbers: 91-xx; Game theory; economics; social and behavioral sciences; 91D25; Spatial models; 91D30; Social networks

\section{Background}

The problem of understanding social and economic development in human societies is one of the most fundamental questions in science and policy (Sen, 1999; Easterley 2002). Despite many studies and general ideas informed by a history of interventions over the last few decades, the problem has remained stubbornly resistant to useful scientific syntheses (Easterley 2002; Duflo and Banerjee 2011). As a result, policies and interventions aimed at spurring human development at different levels from individuals to neighborhoods and from cities to entire nations - have remained limited in their successes and the design of even basic strategies remains the focus of controversy.

Recently, more empirical approaches to problems of development have gained traction, such as randomized control trials (Duflo and Banerjee 2011), longitudinal community studies (Sampson 2012) and censuses of informal communities (Patel et al. 2001) on small scales.

\footnotetext{
* Correspondence: clio@santafe.edu

Santa Fe Institute, 1399 Hyde Park Rd, Santa Fe, NM 87501, USA
}

On larger scales, big(ger) data approaches have also attempted to characterize the structure and dynamics of developing human societies, e.g. via remote sensing of built urban areas (Angel 2012) and the analyses of national mobile communication networks (Eagle et al. 2009, 2010). Nevertheless, there remains a large gap between what these methods and technologies can measure and a detailed understanding of the complex processes that underpin socioeconomic development. Establishing some of these connections is one of the objectives of the present paper.

Policies directed at human development at the urban and national levels have often attempted to change socioeconomic dynamics via improvements of infrastructure and services (Brook and Smith 2001; Nunan and Satterthwaite 2001, Calderón and Servén 2004). However, the nature of the link between the physical, infrastructural and social facets of human societies has remained unclear and difficult to establish in useful ways (Lynch 1981, Calderón and Servén 2004). In practice, the attempt to use engineering solutions, e.g. for the

\section{实


provision of housing or transportation, as the principal driver of socio-economic development has been largely unsuccessful, especially in helping the poorest urban populations in developed nations. Vivid examples of such failures include the top-down policies of urban renewal in the United States and elsewhere after World War II (Mintzberg 1994). These observations raise questions: what kind of social structures and dynamics underlie human socioeconomic development and what properties should infrastructural and physical engineered systems possess in order to support them.

In response, successful human socioeconomic development seems to require the simultaneous co-evolution of social structures and infrastructural networks and services (Jacobs 1970; Holston 2008). Where studied in detail (such as Sampson 2012) various issues of human development, such as unemployment, poor health and violence tend to co-occur at the local (neighborhood) level, suggesting that only integrated solutions that support human development as a whole are likely to be sustainable. Thus, policy targeted at solving one or just a few aspects of the problem, e.g. epidemic outbreaks (Yoneki 2011), emergent political violence (Robertson et al. 2010), or other humanitarian crises (Sarcevic et al. 2012; Starbird and Palen 2011) though certainly important, are likely not sufficient or significantly effective at promoting self-sustaining development. Some nations without such problems still display manifest challenges of development, while other societies, where these problems do occur, show clear and sustained growth.

Therefore, there is an acute need for new concepts and methodologies in terms of specific measurable socioeconomic structures and their dynamics in space and time. Here, we address this problem through a synthesis of ideas from the social sciences, grounded in recent quantitative developments in network theory such as computational social science (Lazer et al. 2009) and theory of cities as complex systems (Batty 2013, Bettencourt 2013). Specifically, we address the fundamental nature of development dynamics as a socioeconomic network process, show how development can be measured using telecommunications data for Côte d'Ivoire from the D4D challenge (Blondel et al. 2012) and suggest how a general path of development could be observed and possibly stimulated. We also propose a set of possible additional measurements and policy interventions that can test the concepts developed here.

We first provide context on general ideas of development and economic growth, and some of their shortcomings when applied to the specific case of Côte d'Ivoire, as well as to most other developing nations.

The problem of understanding economic growth lies somewhat outside the mainstream of conventional economics as it requires relaxing certain concepts of optimality and equilibrium central to microeconomic formulations (Barro and Sala-i-Martin 2003). Instead of focusing solely on factors of production, such as labor and capital, as the source of productivity gains in an economy, modern theories of endogenous economic growth, developed through the 1990s (Romer 1994; Barro and Sala-i-Martin 2003) emphasize the creation of new information in the form of new products, "recipes" or "algorithms", as the source of economic growth. In a nutshell, these theories emphasize the non-rival (non-exhaustible) nature of information. To put it simply, new money comes from new ideas. Human capital, usually measured in terms of educational attainment (Nelson an Phelps 1966, Heckman 2000), plays a central role as the putative creators of this novel information. Yet, education and research and development must be paid through savings (e.g. foregone consumption) to be invested into these activities.

At present, people with advanced degrees in Côte d'Ivoire earn higher wages than those without degrees, according to the International Monetary Fund (IMF) (2009), but are subject to the highest unemployment rates and the longest periods of job search in the nation (Direction des Services Socioculturels et de la Promotion Humaine de la Mairie du Plateau 2009). Thus, the production of a more educated population is statistically not the answer. Instead, a greater emphasis on how innovations are learned and used throughout human societies, such as a focus on skilled, professional and industrial capabilities and product spaces (Leontief, 1986; Hidalgo et al. 2007), seems necessary.

While economic development perspectives emphasize the quality of governance and institutions (Acemoglu et al. 2005), a proliferation of informal employment dominates the economy in Côte d'Ivoire. This type of economic activity is usually associated with low levels of specialization and coordination of labor and adds little value to measurable economic activity (Losby et al. 2002).

While these concepts reflect important ingredients of economic growth and development, they provide no specific theory about where information resides in terms of social structures and specific economic agents, and across scales of organizations from individuals and firms and a larger interaction network. Thus, the crucial question becomes: Why don't developing economies quickly adopt strategies to promote the division and interdependence of labor across scales of organization? And how can we measure how information, capital and opportunity are distributed across such scales?

We propose to address these questions following on two general observations of the characteristics of human social development across time and different societies. First, developed nations are characterized by high levels of individual and organizational specialization (functional 
diversity) and integration, at least at three levels of organization: i) the urban system (nation), ii) cities and iii) firms and other social organizations. At each of these scales we should expect network structures to emerge that entail the exchange of information, as well as people and goods, involved in socioeconomic processes of growth and innovation.

Second, interdisciplinary concepts, grounded in the spatial and temporal characteristic of social connectivity and its evolution as a complex adaptive system may hold the key to answering this question. Development is first and foremost the open-ended process of gaining social and economic access to a society at large. For example, recent ethnographic studies in sociology, especially in Latin America (Holston 2008), have emphasized how new urban migrants living in informal settlements have gradually strived for services and citizenship rights and responsibilities. As a result, large, poor and marginalized fractions of urban populations joined their civic society and formal economies, and gradually raised their socioeconomic status and that of their communities. These processes connect the aggregation of information in human societies to scale, innovation and economic growth (Hayek 1945; Arrow 1962; Holston 2008; Bettencourt et al. 2012).

However, these dynamics have largely remained untested because the comprehensive observation of social structures, from the individual to the nation, was technically impossible until recently. We believe that organizational structures and their dynamics are visible in networks of telecommunication and especially through geo-located individual mobile devices (such as cell phones). In this article, we show how networks of telecommunications provide a new window into measuring fundamental social dynamics that have been outlined theoretically in the past.

\section{Related work and conceptual framework Related work}

The role of infrastructure in the development and economic growth of society has been studied extensively over the last few decades. Empirical studies of the effects of infrastructure development on growth and income distribution have been performed across large number of (developed and developing) nations (Hardy 1980; Röler and Waverman 2001; Calderón and Servén 2004; Datta and Agarwalb 2004; Lam and Shiu 2010; Forestiera et al. 2002, Sahooa and Dashb 2009) and in more specific longitudinal studies of particular countries and regions (Ding and Haynes 2006; Lall 2007; Calderón and Servén 2010; Sahooa and Dashb 2012). Correlation and econometric analyses indicate that economic growth and, often, the reduction of income inequality are positively affected by the stock (in quantity and quality) of infrastructure (Calderón and Servén 2004). These variables also exhibit causal relationships in developing nations in Asia and Africa (Hardy 1980; Röler and Waverman 2001; Ding and Haynes 2006; Lall 2007; Ssewanyana 2007; Calderón and Servén 2010; Sahooa and Dashb 2012; Singh et al. 2013).

The effects of specific kinds of infrastructure on economic growth - especially transportation and telecommunications (Goddard and Gillespie 1986; Röler and Waverman 2001) -are particularly important because they tend to lead to network effects (a.k.a. externalities) that multiply their value as more people and locations are connected (Hardy 1980; Di and Liu 1994; Röler and Waverman 2001; Correa 2006; Sahooa and Dashb 2009; The World Bank 2009; Aker and Mbiti 2010; Gruber and Koutroumpis 2011; Vu 2011). These network effects often support virtuous cycles of infrastructure development and economic growth (Lam and Shiu 2010).

Thus, the role of telecommunications in development has attracted attention and empirical analysis in terms of landline telephones (Hardy 1980; Goddard and Gillespie 1986; Di and Liu 1994) and more recently the Internet and broadband access (Townsend 2001; Vu 2011; Forestiera et al. 2002; The World Bank 2009; Singh et al. 2013) and mobile phones (Abraham 2007; Lam and Shiu 2010; The World Bank 2009; Vu 2011).

Mobile phones are particularly important in developing nations today (The World Bank 2009; Lam and Shiu 2010), potentially leapfrogging the development of previous telecommunications infrastructure, such as landline telephones (Ding and Haynes 2006; The World Bank 2009). In fact, cell phone use in economic activities tends to lead to more efficient markets and greater welfare for producers and consumers, effectively reducing transaction costs (Abraham 2007; Jensen 2007), and has also played a significant role in the dissemination of expert knowledge and services such as medical diagnosis (Breslauer et al. 2009) and banking (Sullivan 2007).

However, with mobile phones and other complex infrastructure, subtler and potentially more problematic effects persist. For example, the introduction of new telecommunications often creates, unearths or exacerbates regional disparities, favoring larger cities and more developed regions and wealthier populations (Goddard and Gillespie 1986; Capello and Nijkamp 1996; Townsend 2001; Forestiera et al. 2002) a trend that we uncover in Côte d'Ivoire below. Other studies emphasize that the effects of telecommunication on economic growth are nonlinear, exhibiting strong scaling returns upon inception (Ding and Haynes 2006; Gruber and Koutroumpis 2011), but also potentially requiring near universal access to realize their full network potential and, in some cases, a level of critical mass penetration (Röler and Waverman 2001; Vu 2011). 
Still, limitations to understanding the role of mobile telecommunications in human development persist. Data remains limited at the microscopic level (Aker and Mbiti 2010). We lack a mechanistic and interdisciplinary framework (Hosmana et al. 2008; Vu 2011; The World Bank 2009; Aker and Mbiti 2010; Miard 2009) that can account for economic impacts as well as general network effects created by emerging technologies. Little is known as to how technologies characterize different modes of economic growth (in formal and informal economic sectors), how agglomeration effects are realized in cities, and how these technologies are integrated at the national level in relation to rural development and migration. Moreover, telecommunication networks play a dual role, both as measurement instruments and as enablers of change, and their persistence and co-linearity in this regard makes them both exciting and difficult to measure.

In response to these challenges and opportunities, we seek a multi-scale, multi-functional understanding of the role of mobile telecommunications in the development of human societies to ensure a more scientific view of temporal and spatial changes, and to provide a method for researchers and practitioners to better develop and test policies.

\section{Conceptual framework}

Using geolocated mobile phone data in Côte d'Ivoire as the illustration, we connect some of the theories discussed above to what dynamics are produced in pointto-point geolocated telecommunications flows. We emphasize quantitative network structures and some of their characteristics across different levels of analysis nation, cities and organizations - as the key observables that can be measured using mobile call records. This in contrast to most of the econometric studies reviewed above about the role of telecommunications in development because i) our dataset has a relatively short time span of 5 months (see Methods), and ii) we feel that there is a gap in the literature in connecting such studies to a network view of the structure and dynamics of social networks that underpin development processes. Thus, in taking this somewhat orthogonal view to much of the extant literature and using a new (increasingly more available) type of dataset we hope to contribute a complementary view of the role of infrastructure complexity to human development.

Our methodological framework supposes that the structure of call networks between cities (Figure 1, top) can diagnose the level of integration of the national
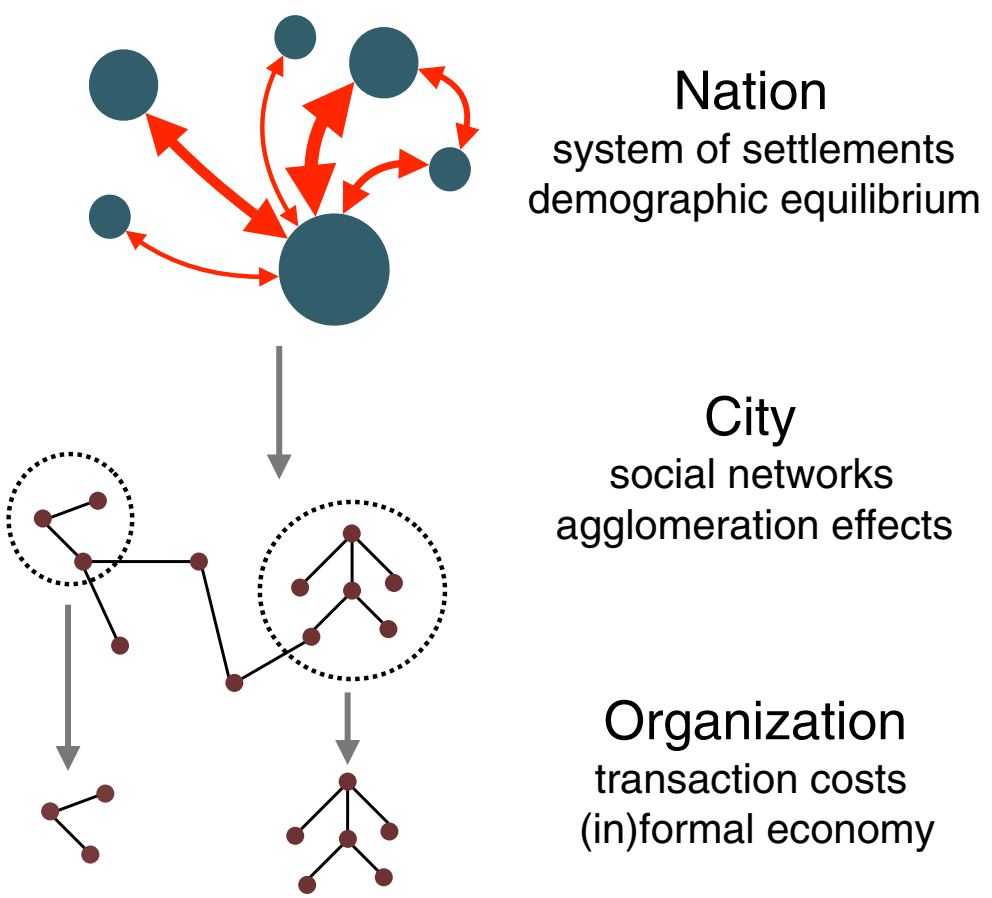

\section{Organization transaction costs (in)formal economy}

Figure 1 Conceptual scheme of socioeconomic connectivity and its functions across scales of organization. At the coarsest level (top) cities and small settlements are connected via information flows that are expected, in well-developed and large urban systems, to be approximately symmetrical, as described by general statistical regularities of communication and movement (gravity laws). At the level of cities (middle) and settlements, social connectivity is expected to reflect increasing returns to population scale in social connectivity (scaling relations) and manifest itself in socioeconomic agglomeration effects, accelerating rates of economic production as well as other social and economic processes both positive and negative, see text. Finally, (bottom) the structure of connectivity is associated with transaction costs that influence social and economic organization and may facilitate informal entrepreneurship. We propose here that all these general expectations have quantitative signatures in the social networks and can be measured and evaluated using comprehensive cell-phone call records data. 
settlement system. It has been observed from many decades that large, integrated urban systems show patterns of exchange of information and of human mobility that are approximately described in terms of a mobility (gravity) law (Isard 1975). We leverage the gravity law as a null model of the expected connectivity patterns between settlements in Côte d'Ivoire, and judge the density and dynamics of actual connectivity patterns from this reference point.

A second level of analysis deals with increasing returns to population size (a.k.a. agglomeration effects) that are internal to cities (Bettencourt 2013). These effects are a consequence of the structure of urban social networks (Figure 1, middle) and constitute the basis for increases in innovation and learning in the city and, as ideas spread, across the urban system. It has been shown that such agglomeration effects have a simple network signature, in that the total number of social connections increases with city population size as a power law, with an exponent (elasticity) of the order of $b=1+\delta$, with $\delta \approx 1 / 6$. The microscopic expression of these effects at the social network level also derive aggregate economic production functions for cities that show increasing returns to population scale, as shown in (Lobo et al. 2013), so that for example wages in larger cities tend to be larger than in smaller towns. We use cell phone network data to test this hypothesis for the cities of Cote d'Ivoire and discuss its implications.

Finally, although the present data does not permit the identification of socioeconomic organizations (Figure 1, bottom), we discuss the role of mobile telecommunications in reducing economic transaction costs (Abraham 2007; Jensen 2007) - associated with labor, goods and information exchanges - and discuss implications in terms of socioeconomic organization, making markets more efficient and facilitating the workings of a large informal economy.

\section{Methods}

Telecommunication network data sources

We use geo-located Call Detail Records (CDR) from Côte d'Ivoire for the period of December 2011 - April 2012 to illustrate the communication patterns between different geographies in Côte d'Ivoire. Data is provided by Orange within the framework of the Data for Development (D4D) Challenge (Blondel et al. 2012).

The CDR dataset provides the geographic coordinates of 1231 cell towers within Côte d'Ivoire, of which 1094 are associated with one or more incoming or outgoing calls during the study period. Calls that originate from a "-1" (e.g. unknown) tower are eliminated from our analyses, as are pairs of cell towers exchanging fewer than 50 calls over the 5 month period. All calls are directed from caller to recipient locations. Data is processed using the $\mathrm{R}$ statistical software package.

\section{Population assignment}

The population of Côte d'Ivoire is distributed among cell towers using population grid data provided by Afripop. org. In this dataset, each grid cell in the raster contains a population value ranging from 1 to 224. Each raster cell is assigned to the cell tower closest to his or her home location (e.g. through a Voronoi/Thiessen polygon). We estimate a 30 kilometer range from each cell tower point (assuming GSM typical ranges), which captures a total of 18,842,000 people nationwide, and renders 256,411 out of range of any cell tower use.

\section{Geographic aggregation and connectivity patterns}

In Figures 2-6, lines connecting different administrative units denote call volume. Loops indicate the magnitude of calls placed and received from the same spatial unit. These are visualized in the ESRI ArcGIS 10.1 environment using administrative boundaries provided by the D4D Challenge (Blondel et al. 2012). The geographic coordinate system used is GCS-WGS-1984.

Calls volume is aggregated into two spatial interaction matrices to examine the frequency of communication between administrative units. These aggregations are made at the 50-district level, and the 235-prefecture levels (where prefectures are nested within districts), based on the location of the cell tower within administrative boundaries. If the cell tower location falls within the boundaries of these administrative units, their call data (number of incoming calls, number of outgoing calls, and population) is summed within the unit.

To analyze neighborhood connectivity, we divide Abidjan into communes geo-coded from a number of maps of the area (provided by maps from Microsoft Bing and Google Maps). The set of geographic units consists of 10 communes, as well as three suburbs, Bingerville, Songon and Anyama. Calls are then aggregated based on cell towers within these spatial units.

Prefecture-to-prefecture calls range from 101 calls (exhibited by many prefecture pairs, such as M'Bengue to Toumodi) to $105,351,197$ calls that both originated from and were received in Abidjan. District-to-district calls range from 101 calls (exhibited by three district pairs such as Danane to Adzope) and also peak with internal Abidjan district calls.

\section{Results and discussion}

We now analyze the quantitative characteristics of networks of connectivity at the national and urban levels. We begin by describing nationwide connectivity patterns, then those of the nation's largest city, Abidjan. We then discuss how certain quantitative signatures of mobile telecommunications connectivity can characterize how well integrated an urban system is and measure the presence of urban agglomeration effects. 


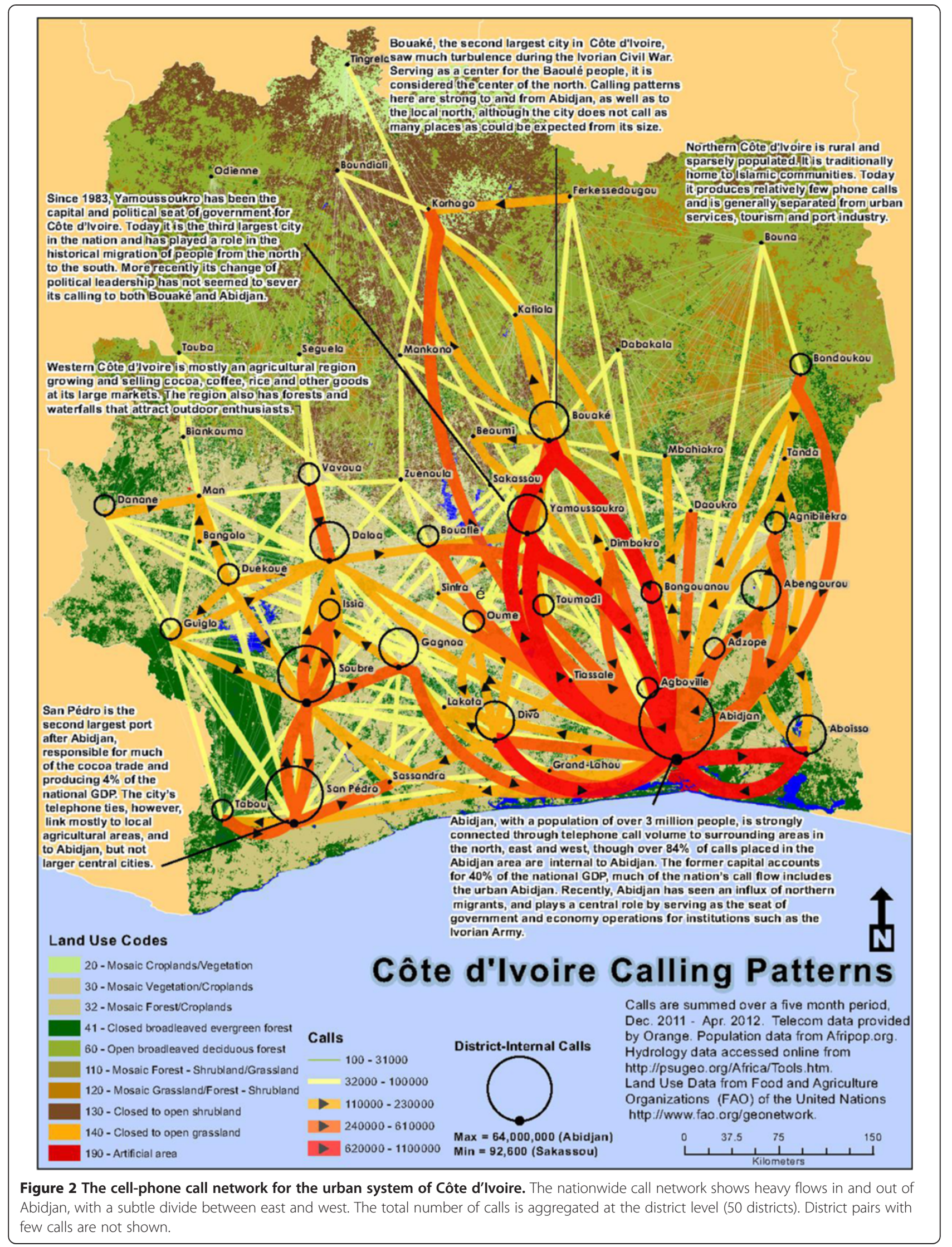




\section{Telecommunication patterns in Côte d'Ivoire's urban system}

For a nation to develop, it is essential that each of its locations is integrated into an urban system made up of inter-dependent cities that exchange people, goods and information (Fujita and Mori 1997). This is because it is across cities of different sizes that the advantages of large urban areas, in terms of innovation and organization, pay off. In this view, development happens through the incorporation of new ideas and organizational forms into the structure of industrial and primary production, which, in turn, form the principal basis for the economies of smaller cities, and the material basis for nations as a whole (Christaller 1966; Lösch 1954, Fujita et al. 2001).

In theories of central place (Christaller 1966; Lösch 1954) later elaborated by modern economic geography (Fujita et al. 2001), the crucial feature that provides the basis for intercity dependences is a functional hierarchy of economic functions. This means that the largest city in the system contain (but is not self-sufficient in) all economic functions observed in smaller ones, but not the reverse. As such, larger cities supply services (innovation, information, organization) to smaller cities in their territory, primarily in exchange for food and other material goods. The largest city in an urban system is thought to service, in this way, an entire nation. Despite some urban specialization, such as in large-scale manufacturing, these trends are characteristic of most developed nations (Mori et al. 2008; Hsu 2012). Here we investigate if these patterns are characteristic of the Ivorian system of cities.

Detailed and reliable information about economic functions is still hard to obtain at the city level, especially in developing nations. Nevertheless, telecommunication data gives us an entry point to investigate to what extent Côte d'Ivoire's urban system is spatially integrated, and to measure the roles of distinct cities in light of the expectation of a national urban hierarchy expressed in terms of telecommunication call flows. In other words, it is not enough to assume that cities of different sizes serve purposes in a larger network without knowing how they are connected as a network. With telecommunications network data, this becomes possible.

In this section, we examine the structure of the networks of telephone calls between prefectures in Côte d'Ivoire. A map of the total number of calls (placed and received) between any two places in the urban system shows, as would be expected from central place theory arguments, the importance of the largest city, Abidjan (about 3.8 million people) (Figure 2). The connection to Abidjan is expressed in terms of the diversity and strength of calls exchanged with many other cities in the nation. However, even at this level we start to observe that links to Northern and Western parts of the country are relatively sparse. The political capital Yamoussoukro also plays no particularly strong role in this network, despite its expected behavior of connecting to the two large population centers, Abidjan and Bouaké (pop. $\sim 775,000$ in 2002).

These patterns become clearer when we consider calling behavior between any two places on a per capita basis: That is, when we ask what the typical calling patterns of an individual subscriber in a given city may be. Calls placed (Figure 3A) and received (Figure 3B) per capita show that larger cities, Abidjan in particular, are large hubs in the national communications network. These calling patterns show that much of the nation of Côte d'Ivoire is actively listening to what happens in Abidjan. As for Abidjan itself, most of the calls it places $(84 \%)$ are to other parts of the city. (Note that it does not follow necessarily that Abidjan obtains its information from other parts of the city, as the large developing metropolis likely also possesses strong links to other international cities, not provided in the D4D dataset).

Apart from Abidjan, the second largest city, Bouaké, plays an analogous role, but more limited to its immediate neighboring region. Interestingly, the political capital Yamoussoukro, does not escape this pattern: its strong connections to the two largest cities are more in placing calls rather than receiving them. Other economically important regional centers, such as San Pedro (the second largest port, after Abidjan), have more mixed patterns of connectivity, separate from those of the other larger cities. Though already seen in Figure 2, the northern and western parts of Côte d'Ivoire are also largely disconnected from the main economic and political centers of Côte d'Ivoire when viewed on a per capita basis.

To quantify these patterns of communication fit a simple gravity model to call data. This models the volume of calls between two places $i$ and $j, C_{i j}$ as

$$
C_{i j}^{\text {gravity }}=G \frac{N_{i} N_{j}}{d_{i j}^{g}},
$$

where $G$ is a constant, $N_{i}, N_{j}$ are the populations of the two cities, and $d_{i j}$ is the (Euclidean) distance between them. The parameters $g$ and $G$ are obtained by fitting Eq. (1) to call data. We obtain a reasonably good fit $\left(R^{2}=0.42\right) \quad$ with $g=2.13 \quad(95 \%$ confidence interval $[2.02,2.24])$ and $G=0.002 \quad(95 \%$ confidence interval $[0.001,0.003])$. In practice, the exponent $g$ is empirically observed to vary for different datasets, for different nations at different times, around the value $g=2$. The present value is similar to that obtained by (Krings et al. 2009) for Belgium.

We now use this best-fit gravity model as the generator of a set of null expectations for the volume of calls between any two places in a well-developed urban system. 


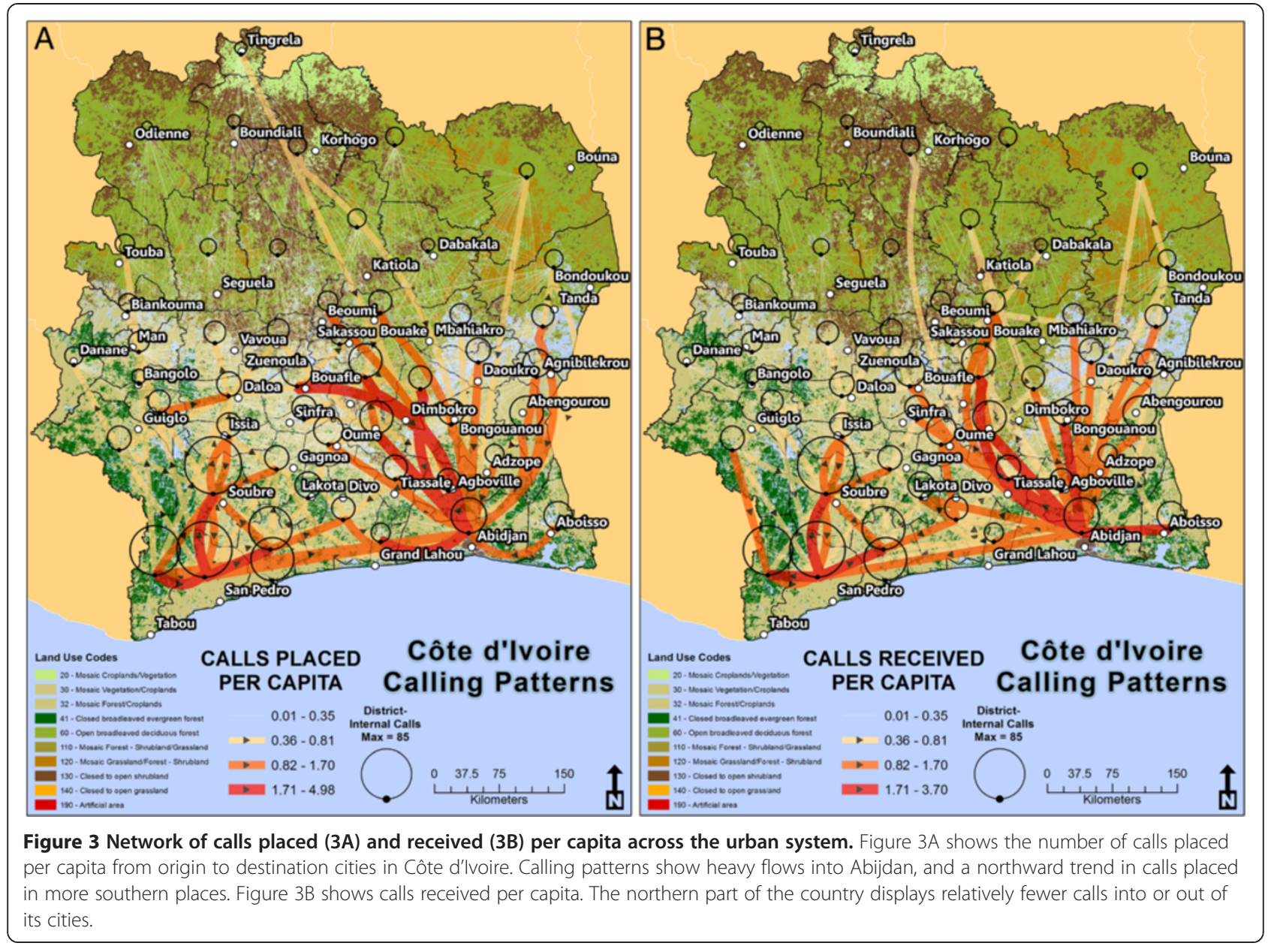

Figure 4 shows the residuals of the gravity model fit, as the difference between the logarithm of actual calls and the gravity model prediction: $x_{i j}=\log C_{i j}-\log C_{i j}^{\text {gravity }}$. For $x_{i j}>0$ (red) two places communicate more than expected by the gravity model, while for $x_{i j}<0$ (blue) the converse is true. We observe a pattern where the south of the country, and especially its southwestern region, including San Pedro, is the most interconnected. Though the population is sparse in the region this finding may illustrate the burgeoning power of the coastal port industry and its relation to inland cocoa and coffee production. Conversely there is a much weaker pattern of connectivity from the South to the North and from East to West (illustrated also in Figure 2, Figure 3). These structured patterns of underconnection are somewhat surprising as Côte d'Ivoire is often thought to be primarily divided between a poorer, more Muslim, north and a more affluent, Christian South.

This network structure suggests that the Ivorian urban system is still very much incipient. Most cities display strong communication links regionally, but it is clear that even Abidjan (the economic capital) and especially Yamoussoukro (the political capital), though displaying a greater reach than smaller cities, fail to maintain a network of communication with most of the nation, especially the North and West, which are, not coincidentally, the poorest parts of the nation.

When regions are disconnected, it is more difficult for the nation to take advantage of the social, human and economic capital produced in various parts of the country. This predicament of inaccessibility becomes even direr when communications and travel infrastructure are not fast, affordable and reliable, and can be deleterious to the nation's economic progress. This suggests that a path for national development must entail improvements in the integration of the nation as a whole (Hardy 1980; Goddard and Gillespie 1986; The World Bank 2009), and should be facilitated and accompanied with the observation of increasing call rates between all places, and especially between the larger cities and the western, southwestern and 


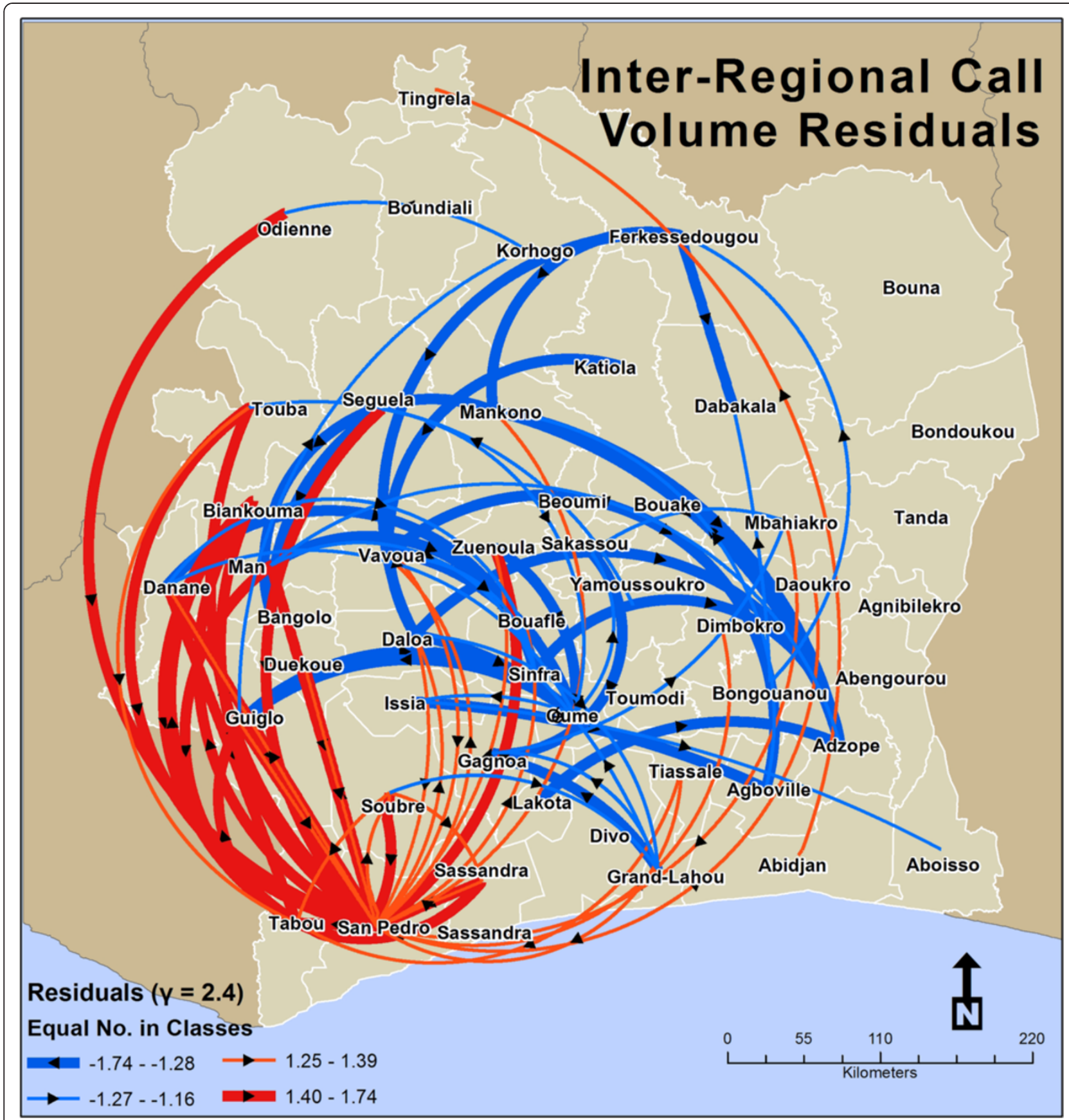

Figure 4 Deviations in calling patterns from gravity null model. Pairs of places that exceed the null gravity law expectation (see text) by 1.0 or more (log of calls) are shown in red, while those that perform under this expectation by -1.0 (log of calls) or less are displayed in blue. This pattern shows over-calling in the southwestern region, including San Pedro, and under-calling east-to-west, indicating little cross-longitudinal connection between the nation's regions.

northern parts of the country. We discuss the effects that may serve as indicators below.

\section{Urban agglomeration effects}

Large cities are often described as the social, political and economic engines of most (developed) nations. However, it has also been argued that recent urbanization in many parts of Africa has apparently failed to deliver on its promise for economic development (The Economist Online 2012) and has proceeded without much to show in the way of measurable economic growth. These issues are subtle, however, as we discuss below in the context of Côte d'Ivoire. 
Generally, historical and contemporary patterns of national development very much depend on the socioeconomic dynamics that happen inside a nation's largest cities and in particular on the ability of these places not only to grow but to realize increases in social interactivity that can lead to larger and more sophisticated economic specialization and interdependence; organizational and technological innovation; and the seizing of latent economies of scale in services and infrastructure (Bettencourt et al. 2012; Jones and Romer 2010).

Arguments from complex systems theory and from urban economics emphasize the role of agglomeration economies in all these processes: the output of socioeconomic processes rises on a per capita basis with the size of cities. This is interpreted in terms of the possibilities for interaction created by spatial and temporal concentration of people in cities (Bettencourt 2013, Lobo et al. 2013). However, even if these conditions are met, the question remains whether cities realize these interactions for good or for ill. Negative consequences of increased human interactivity can also occur, in terms of increases in crime rates, the prevalence of infectious diseases and the proliferation of small-scale informal economic agents. The cities of Côte d'Ivoire, and Abidjan in particular, manifest these various consequences of urbanization: The good and the bad are very much intertwined, as we discuss below. Telecommunications data can help in the determination of not only which cities are involved in this type of growth, but also provide metrics of to what extent agglomeration effects are realized in each place.

In addition to analyzing nationwide regional connectivity (Figures 2 and 3), and the deviation from an expectation of these patterns (Figure 4), we also examine the communication patterns in the region and central city of Abidjan (Figures 5 and 6, respectively). At the metropolitan level it is clear that Abidjan thoroughly integrates

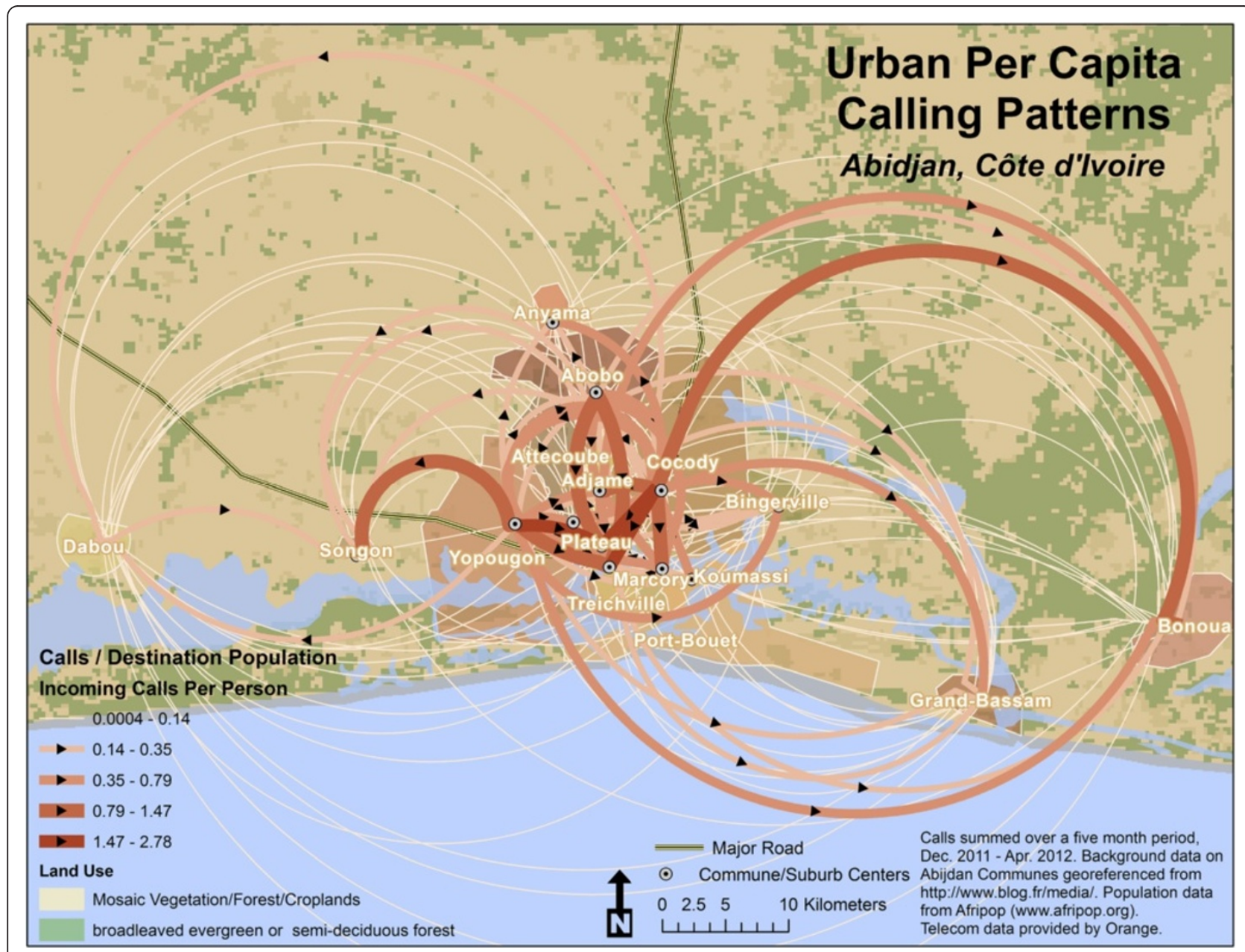

Figure 5 Urban per capita calling patterns in the Abidjan Metropolitan Region. The regional call network for Abidjan shows activity in the dense downtown, as well as connectivity from the northern community of Abobo, and from the western community of Songon, to the downtown. In addition, high flows are found from the downtown to the eastern area of Bonoua, and to a lesser extent, port town Grand-Bassam. These patterns suggest that communication within Abidjan is well developed. 


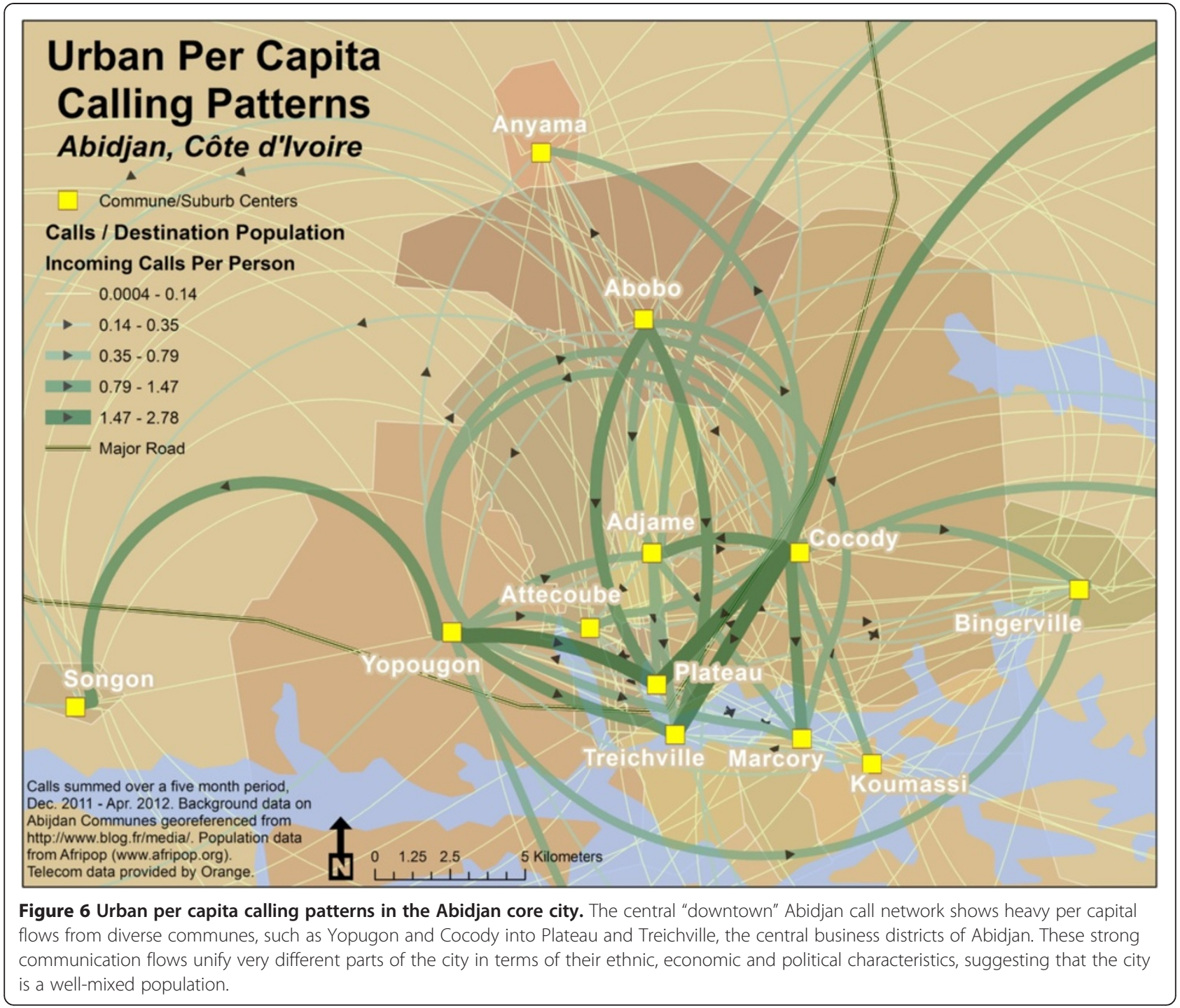

its central communes, between and within surrounding population centers, such as Anyama, Bingerville, Bonova, Dabou, Grand-Bassam and Songon (Figure 5).

Central communes in the city exchange information even more frequently than with these other adjacent areas (Figure 6). Especially noteworthy are the almost parallel roles of the two population centers of Yopougon (most populated commune) and Cocody (most affluent residential district), and in a different way the commercial and business centers of Adjamé and Plateau. Interestingly, the commune of Abobo, which also has a large population, to a large extent of internally displaced migrants, is less connected than Yopougon to the rest of the city. Nevertheless, these figures strongly suggest strong communication patterns between ethnically, functionally and economically different parts of the city, which are a sign of functioning urban center as a mixing social network (Bettencourt 2013).
This suggests that even if Côte d'Ivoire remains relatively disconnected as an urban system, local socioeconomic connectivity within cities seems to thrive (most clearly in Abidjan) and can facilitate general processes of urban agglomeration.

To test this idea in greater detail beyond Abidjan, we perform a simple scaling analysis for the total number of calls received by each prefecture as a function of their population. These patterns are well described on average by a power law function (Bettencourt et al. 2007; Bettencourt and West 2010; Bettencourt 2013) where the connectivity, $C$, is a function of population size $N, C=C_{0}$ $N^{b}$. The parameter $b-1$ measures the on average increase in social connectivity per capita with city population size. We observe, $b=1.26$ (95\% Confidence Interval [1.19, 1.34]) implying that connectivity per capita increases by about $26 \%$ with each doubling in population size (Figure $7 \mathrm{~A}$ and $7 \mathrm{~B})$. These scaling effects are in line with patterns 

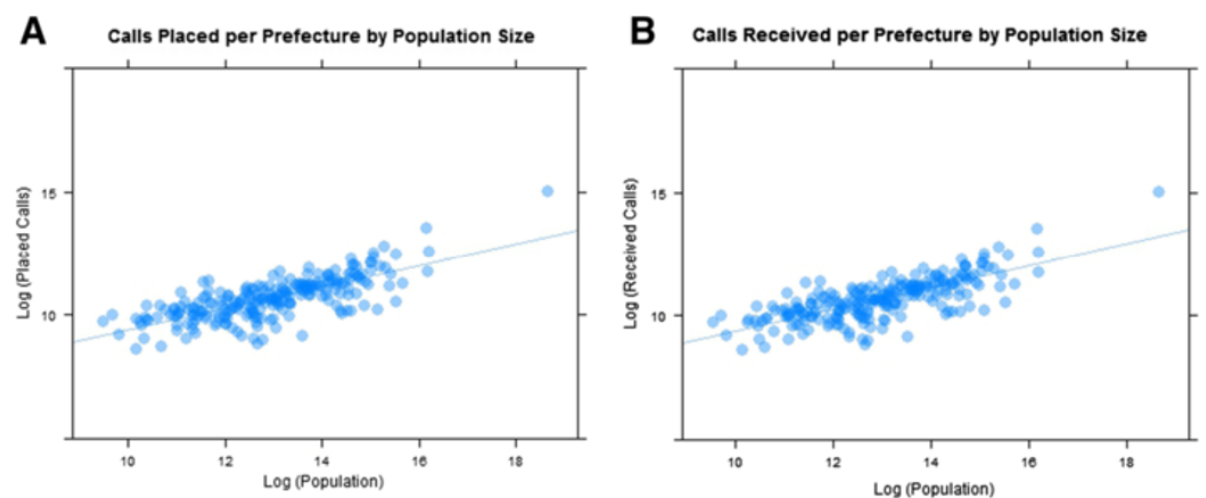

Figure 7 Number of calls placed (7A) and received 7B) by each prefecture. Cities (prefectures) with larger populations produce (7A) and receive (7B) more calls on average, indicating that dense communities (e.g. cities) exhibit more telecommunications activity per capita.

recently measured for analogous telecommunications data in Portugal and the United Kingdom (Schläpfer et al. 2012) and predicted by urban scaling theory (Bettencourt 2013). They suggest a general acceleration of social economic processes with city size in agreement with many other nations, developing and developed (Bettencourt et al. 2007; Bettencourt and West 2010; Bettencourt 2013). In line with the observations of the previous section, upon isolating internal calls, we find that growth in connectivity with population size that is due to internal calls within each city is even faster, with a $b=1.49$ (95\% Confidence Interval $[1.39,1.58])$. This means in practice that as Ivorian cities grow the fraction of all calls that is internal to the city increases. In Abidjan, $46 \%$ of all calls initiated in the city are to callers within the city.

Moreover, the joint signature of urban agglomeration effects and of an urban hierarchy should be visible in patterns of diversity of connection and city size (and therefore of economic productivity, see below), as has been observed for the U.K. using telecommunication networks (Eagle et al. 2010). We find similar results showing how simple measures of diversity: the total number of unique places called from a city and the Shannon entropy of such call patterns (Shannon 1948), increase on average with city size (Figure 8).

That cities in Côte d'Ivoire generally realize agglomeration effects is good news for national development. However, it is also important to understand what effects of urbanization are enabled by social interactions, benign or malign (Bettencourt et al. 2007). The recent history of Côte d'Ivoire, which has many parallels with other examples of urbanized Africa and Latin America, indicates that its most recent rapid urbanization is partially the result of conflict and political crises, and less of planned migration to access social and economic opportunity. Abidjan, for example, has grown explosively in population during the last decade of conflict in the region, due to both internally displaced people and refugees from neighboring nations.

Nevertheless, and despite these challenges, rates of poverty in Abidjan are lower than in all other parts of the country (21\% compared with $49 \%$ for the nation) (International Monetary Fund 2009), especially in comparison with rural areas. Urban GDP is largely unknown. However general estimates suggest that Abidjan is responsible for about $40 \%$ of national GDP, whereas northern, landlocked Bouaké accounts for about 3\% and San Pedro, an important port for cocoa exports, accounts for $4 \%$. Accounting for their respective populations results in an annual per capita GDP of 3,677, 1,337 and 4,857 USD respectively, considerably larger than the national GDP per capita of 1,062 USD. Perhaps clearer are the results of the most recent Survey of Living Standards of Households in 2008 (via International Monetary Fund 2009). Its findings regarding personal income illustrate more fully the relative economic advantages of urban centers and of Abidjan in particular. The findings of this survey estimate that all urban centers in the nation manifest larger incomes than their surrounding rural areas by factors of 1.3 to 1.9 (national average is that urban incomes are 1.82 larger than rural ones). The annual average per capita income in Abidjan is by far the largest in the nation at about 561 thousand CFAF (roughly \$1140 USD) compared with 372 thousand CFAF (roughly $\$ 695$ USD) for the national average. In 2007, Mercer Human Resources Consulting, who rank cities around the world in terms of their quality of life, placed Abidjan as $35^{\text {th }}$ most expensive city in the world! Thus, economic urban agglomeration effects are at play in Côte d'Ivoire, even if national GDP (and incomes) may have recently decreased in real terms, during the last decade of conflict. 

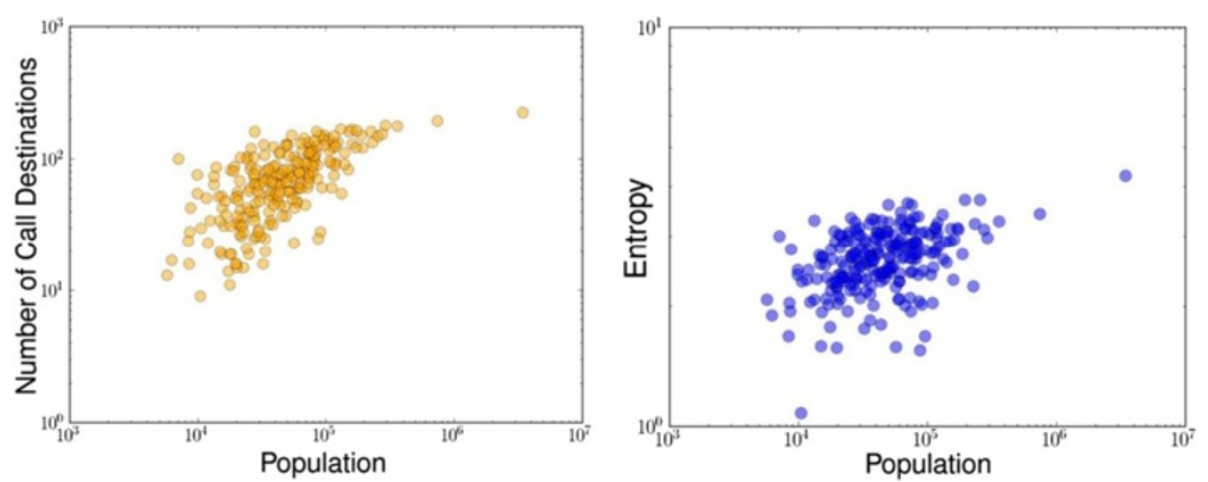

Figure 8 The relationship between call destinations, entropy and city size. The relation between number of cities called and the population size of the origin (left), and the relation between the diversity (Shannon entropy) of calls placed and population size of cities (right) show an upward trend.

Other more sinister urban agglomeration effects point to some of the challenges of development in Ivorian cities. It has been estimated that $4.7 \%$ of the country's population is infected with HIV/AIDS (International Monetary Fund 2009). According to the same survey, in Abidjan, the prevalence of the virus is much higher, at $6.1 \%$. Already in 1997, about $40 \%$ of hospital beds in Abidjan were occupied by HIV/AIDS patients. Urban insecurity is also high, though few reliable numbers exist. The same IMF report stated that in the first half of 2008, out of a total of 62,424 offences to the penal law registered by the National Police, $75 \%$ were registered in the district of Abidjan.

In parallel, economies of scale in urban infrastructure, a general characteristic of cities worldwide, seem to be at best only incipient in Côte d'Ivoire. While it is in the nation's large cities that access to sanitation, treated water, power, and other general services is at all possible these services work mostly intermittently and in small scales, thus squandering some of the possible system-wide savings made possible by large population concentrations. Nevertheless, the already existing urban agglomeration effects and spatial concentration of population in cities presage that Ivorian cities should immediately benefit from realizing economies of scale their urban infrastructure improves. Complex systems theory of cities gives expectations for the general properties for these infrastructural networks as they develop in tandem with socioeconomic quantities (Bettencourt 2013).

All these results, and many more relating to the concentration of services such as police forces, businesses types (Sleuwaegen and Goedhuys 2002) and education, strongly suggest that urban agglomeration effects are already at play in Côte d'Ivoire's cities. However, many of the negative consequences of increased social connectivity, such as high levels of violence and incidence of infectious diseases, may trump some of its economic gains. This pattern is historically typical. Development happens as large problem-plagued cities build infrastructural, political and civic organizations that allow them to systematically tackle problems of population agglomeration (Hall 1998). How mobile communications may play a new role in enabling such solutions is discussed below.

\section{Entrepreneurship and informality}

Finally, and more speculatively, the somewhat poorly known structure of employment and economic entrepreneurship in Côte d'Ivoire suggests that most economic activity in urban centers is concentrated in small and unspecialized organizations, with some exceptions in terms of electricity and cement production, as well as activity in the international ports of Abidjan and San Pedro.

The IMF has, in fact, recently described the informal economy of Côte d'Ivoire as 'vibrant' (2009). It is estimated to have engaged roughly 4,107,595 workers in 2002 vs. $1,698,300$ workers in 1995 , an increase of $142 \%$ over 7 years. Much of the informal sector is rural, but informal employment in Abidjan is estimated to be about $75 \%$ (United Nations Development Program 2004).

Given the increases in social connectivity afforded by urbanization and mobile communication, why haven't larger and more sophisticated firms emerged in Côte d'Ivoire? In economic theory, firms are thought to emerge as a result of the minimization of transaction costs, which must always be incurred in real markets (Coase 1937). Examples of such costs are purchasing of parts and services external to the firm, supplier and client contracts and personnel hiring. These market costs become prohibitive when sophisticated production, involving the integration of specialized skills, is at play. As a result, specialization and learning occurs frequently inside firms.

Mobile telecommunications play a potentially interesting role in promoting social coordination, minimizing market transaction costs, and in promoting social 
organization that could result in the growth and sophistication of economic production. Thus, we hypothesize that in many informal economies cell phones may have encouraged on-demand labor arrangements that may, in fact, defeat the potential for larger firms with more extensive division of labor and specialization of knowledge to emerge. Certainly, that seems to be the case of Côte d'Ivoire in recent years (Ilahiane and Sherry 2008), where, judging from older data from around 1990, the size distribution of firms was characterized by a "missing middle": most economic enterprises were either large, or very small (Sleuwaegen and Goedhuys 2002).

The following example from the transportation sector illustrates how informal market solutions have been trumping potentially more efficient large-scale services: in Abidjan, mass transportation is mainly operated by the public company SOTRA. In 2000, after a decade of disinvestment, its services translated into one bus for more than 4,500 inhabitants, rendering inevitable disaffection for its services. To fill this gap for an essential urban service, informal transport operators (using minibuses called "gbakas" and "504 s") rose to the occasion. Their fleets are estimated at about 6,026 vehicles, while that of regular taxis also swelled to about 8,000 vehicles, with yet another solution (communal taxis or "wôrowôrôs") accounting for another 11,971 units. Not only did these informal businesses fill a gap in transportation services, they also illustrate the immense opportunities for integration and formalization of new economic initiatives within the city.

Mobile communications play a significant, though perhaps obfuscated, role in the scaling up in scope and quality of informal urban businesses into modern economic sectors. In a tumultuous economy, where little is guaranteed day-to-day, mobile phones make possible real-time coordination of logistical changes that rely on weather and event conditions, knowledge of flux in consumer demand, and inventories (such as a van). The ability to transfer valuable information in real time, can allow Ivoirians to make more informed decisions as part of their business practices.

New pricing models and innovative uses of telecommunication services may provide necessary incentives to make these businesses visible, measurable and scalable, while preserving their economic basis and essential services to the public. Such measures may also promote greater trust and satisfaction at the urban level and new economic models that can be exported to other cities.

\section{Promoting social connectivity for development}

We have noted that some of the challenges of development in Côte d'Ivoire, as in other developing nations, may result from a lack of socioeconomic integration capable of encouraging individual specialization, learning and interdependence, from the level of the firm to that of the nation.

We now turn the problem around and suggest that the role of mobile communications in developing societies may be changed from diagnostic to cure: If the problem is the promotion of certain kinds of social connectivity, then new uses and subscriber models in telecommunication services should help promote desirable solutions. Moreover, the interplay between observable telecommunications social connectivity patterns and economic performance is, as we showed here, observable empirically. This provides a new opportunity for creating a feedback process between experimentation of products that encourage social connectivity and performance assessment. This is, we propose, the crucial new dual role that telecommunications can play in urban (developing) societies, as both social "sensors" and "connectors", or, put another way, as both diagnostics and potential cures.

At the national level, greater integration may be obtained by promoting better coverage and product adoption in rural areas and by attractively pricing long distance calling, especially with urban centers (Goddard and Gillespie 1986; Capello and Nijkamp 1996; Townsend 2001; Forestiera et al. 2002; The World Bank 2009). Economic activity could be further promoted with subscription plans that emphasize these properties targeted at businesses. Calling distant and rural areas from urban centers, and promoting urban solutions related to issues of modern technological practices in agriculture, services, telemedicine, and telebanking may help spread urban know-how to poor and remote areas. In return, primary sector increases in productivity may substitute for food and other material imports and enlarge the opportunities for exports at the urban system level (Jacobs 1970). Mobile phones have the potential to play a greater role in this type of economically relevant information transfer.

Inside cities, problems seem to be less predicated on the lack of overall connectivity, but rather on the promotion of its uses for more socioeconomically productive ends. A related question is how to encourage better urban services at larger scales, by exploring latent economies of scale. Calls and messaging that can convey information about urban services and help organize the public to demand their improvement could be made very inexpensive, for example. Crowd-sourced and volunteered geographic information (VGI) models for sharing information about the quality and quantity of public services can be made visible beyond the city and nation to leverage external influence to promote better organizational political and technological sustainable solutions. A system for demanding and rating the quality of public services, such as law enforcement, and to create e.g. crime hot-spot maps, that are visible not only to urbanites directly involved but to the world at large can 
also create a system of incentives for development. Mobile telecommunications allow each individual to be a reporter; while quality control is essential, this holds enormous possibility to bring problems to the light of day and promote coordinated larger scale solutions through political and civic organization. This bottom-up type of information transfer not only adds more eyes to gather information, but can sidestep traditional government and media outlets that may not be sufficiently lubricated to gather and let information flow quickly and freely throughout a nation.

Finally, subscriber pricing models that encourage the formation of visible and formal small firms, by shifting the structure of corporate transaction costs, may help create a culture of small formal entrepreneurship that is the basis of most job creation and innovation in developed societies (Haltiwanger et al. 2013). This may be achievable by lowering the costs of communication for small formal businesses with one another, and raising costs for private individuals, in relative terms, at least. The role of telecommunications in making financial transactions more transparent and formal is also an area that holds much promise in cash fund transfer models and small to medium-scale financing (Sullivan 2007) through the use of mobile devices, for example.

\section{Conclusions}

Mobile telecommunications have quickly come to dominate most distant human interactions, playing a fundamental new role in the communication of information and the coordination of social and economic activities in human societies. We proposed here a framework to formalize multidisciplinary concepts of socioeconomic development in terms of measurable telecommunications network data at three levels of aggregation: individuals and firms, cities, and the urban system. We gave evidence from the data from the D4D Challenge for Côte d'Ivoire that lack of socioeconomic integration is likely a general factor impeding development at the national level and suggested both diagnostics and solutions to promote the dynamics of connectivity and information exchange that can encourage processes of sustainable development. We also showed that agglomeration effects predicted by urban scaling theory are already apparent in the networks of telecommunication in Côte d'Ivoire and that, in light of these results, urban development depends instead on the promotion of their uses for economic growth and social development, including through the expansion of formal entrepreneurship.

Several empirical caveats apply to our analysis. First, in Côte d'Ivoire the telecommunications market is presently exploited by four operators, which share more than 9 million subscribers, out of a population of about 20 million. Of these, the Orange dataset analyzed here comprise of about 5 million subscribers (Blondel et al. 2012). Thus, issues resulting from variable regional market share and biased geographical coverage may affect our results. This information was not provided with the data for the D4D challenge but should be incorporated in future analyses in order to make scientific findings more reliable and useful.

Second, longitudinal data over periods of many years would be necessary to test the association between the structural changes in telecommunication networks proposed here and several aspects of socioeconomic development, which have been the focus of much of the literature on the subject from applied economics (see related work). This is of course possible and may become a reality in the near future. We expect that substantial theoretical and practical breakthroughs can be made

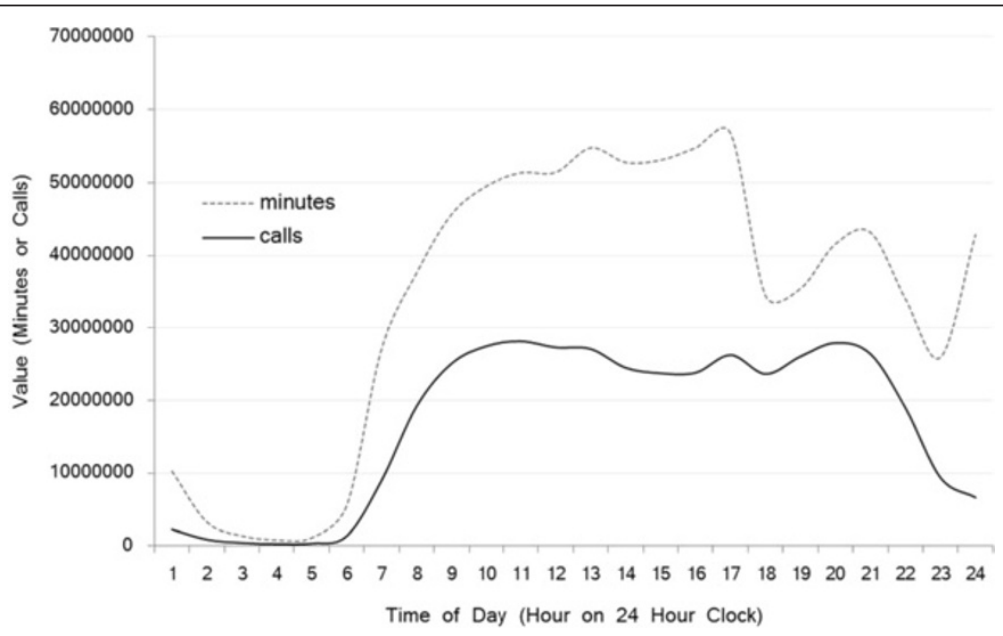

Figure 9 Temporality patterns of phone activity. Temporal patterns of total call volume and call duration (in minutes) for phone activity in the study period shows a spike during business hours, and another spike in the evening. 
when these cross-sectional and longitudinal perspectives can be explored in tandem.

Third, an identification of economic agents such as firms vs. private individuals would be necessary to study the microscopic social and economic dynamics of formal and informal entrepreneurship. Again, this is possible in practice but will depend on issues of privacy and economic competition. A telephone call results from a mutual desire to transfer information over geographic space. Studies suggest that in developing countries the telephone is used more often for personal reasons than for business (Donner 2009). Yet, in the informal economy, many social or business ties can hardly be distinguished. Most calls in the D4D dataset take place during business hours, with clear increases in call volumes from 9 am-5 pm, suggesting that a large part of all calls relate, to some extent, to business (Figure 9).

Information transfer is necessary to organize both formal and informal economic activity. For example, communication is important for finding work for day laborers. In this case, calls may help organize information about job availability, conditions for work (e.g. weather, daily pay), availability and price of market goods (e.g. crops) for sale. In a formal economy, these calls may be less necessary because there are longer-term (labor and price) arrangements and organizations that ensure the reduction of transaction costs in economic activities. In this case, other forms of communication may take their place as economic interdependence between individuals and firms in more complex economies develops. Thus, a change in communication patterns relating to social and economic activities is a necessary condition for development.

In this light, we articulated general characterizations of the telecommunications network in Côte d'Ivoire at three levels of analysis, from the national urban system to cities to individuals and firms. At each of these levels, based on existing theory, we proposed types of change in social interactivity patterns that may encourage dynamics of development and suggested how these may be spurred by telecommunication services that explicitly target such opportunities.

Clearly the hypotheses developed here will require extensive testing and refinement, and access to more data, especially over time and with more careful consideration of important socioeconomic units of analyses, from individuals to businesses and places. As this is done, however, we believe that network analysis of large-scale human interaction data can start delivering on its potential to be a transformative tool for understanding and promoting the socioeconomic development of all human societies.

\section{Competing interests}

The authors declare that they have no competing interests.

\section{Authors' contributions}

Both $L M A B$ and CA carried out the research design. LMAB wrote the majority of the manuscript. CA created the maps and carried out the data preparation and modeling. Both LMAB and CA conceived of the study, and participated in its design and coordination. All authors read and approved the final manuscript.

\section{Authors' information}

Clio Andris is postdoctoral fellow at the Santa Fe Institute specializing in GIS modeling and the analysis of social systems, social networks, interpersonal relationships and institutions within geography and for urban planning initiatives. She will be an Assistant Professor of GlScience (starting Fall 2014) at the Pennsylvania State University, Dept. of Geography.

Luís M. A. Bettencourt is a professor of complex systems at the Santa Fe Institute. He was trained as a theoretical physicist and presently works primarily on empirical analyses and theory development of several aspects of human social dynamics. He is especially interested in building new multidisciplinary quantitative syntheses of cities and urban systems as complex adaptive systems by integrating their social, physical and infrastructural facets.

\section{Acknowledgements}

We thank Vincent Blondel and the Data for Development (D4D) Challenge sponsored by Orange for access to the data and Jose Lobo for discussions. This research was partially supported by the Army Research Office (grant no. W911NF-121-0097), John Templeton Foundation (grant no. 15705), the Bill and Melinda Gates Foundation (grant no. OPP1076282), the Rockefeller Foundation, the James S. McDonnell Foundation (grant no. 220020195), the National Science Foundation (grant no. 103522).

Received: 27 January 2014 Accepted: 4 June 2014 Published: 12 December 2014

\section{References}

Abraham R (2007) Mobile phones and economic development: evidence from the fishing industry in India. Inform Commun Tech and Develop 4:5-17

Acemoglu D, Johnson S, Robinson JA (2005) Institutions as a fundamental cause of long-run growth. In: Aghion P, Durlauf SN (eds) Handbook of economic growth. Elsevier, Amsterdam

Aker JC, Mbiti IM (2010) Mobile Phones and Economic Development in Africa, Center for Global Development Working Paper No. 211. Available at SSRN: http://ssrn.com/abstract=1693963 or http://dx.doi.org/10.2139/ssrn.1693963

Angel S (2012) Planet of cities. Lincoln Land Institute, Cambridge, MA

Arrow K (1962) The economic implications of learning by doing. Rev Econ Stud 29:155-73

Barro RJ, Sala-i-Martin XI (2003) Economic growth. MIT Press, Cambridge, MA

Batty M (2013) A theory of city size. Science 340:1418

Bettencourt LMA (2013) The origins of scaling in cities. Science 340:1438-41

Bettencourt LMA, West G (2010) A unified theory of urban living. Nature 467:912-3

Bettencourt LMA, Lobo J, Helbing D, Kühnert C, West GB (2007) Growth, innovation, scaling, and the pace of life in cities. Proc Natl Acad Sci U S A 104:7301-6

Bettencourt LMA, Samaniego H, Youn H (2012) Professional diversity and the productivity of cities. arXiv preprint arXiv:1210.7335

Blondel VD, Esch M, Chan C, Clerot F, Deville P, Huens E, Ziemlicki C (2012) Data for development: the D4D challenge on mobile phone data. arXiv preprint arXiv:1210.0137

Breslauer DN, Maamari RN, Switz NA, Lam WA, Fletcher DA (2009) Mobile phone based clinical microscopy for global health applications. PLoS One 4(7):e6320

Brook P, Smith W (2001) Improving access to infrastructure services to the poor: institutional and policy responses. Available via World Bank. http://microdata. worldbank.org/index.php/citations/1123. Accessed 15 Jun 2013

Calderón C, Servén L (2004) The Effects of infrastructure development on growth and income distribution. World Bank, Washington, D.C

Calderón C, Servén L (2010) Infrastructure and economic development in sub-saharan Africa. J Afr Econ 19:113-87

Capello R, Nijkamp P (1996) Telecommunications technologies and regional development: theoretical considerations and empirical evidence. Ann Reg Sci 30:7-30

Christaller W (1966) Central places in Southern Germany. Prentice Hall, New York 
Coase RH (1937) The nature of the firm. Economica 4:386-405

Correa $L$ (2006) The economic impact of telecommunications diffusion on UK productivity growth. Inf Econ Policy 18:385-404

Datta A, Agarwalb S (2004) Telecommunications and economic growth: a panel data approach. Appl Econ 36:1649-54

Di AZ, Liu J (1994) Telecommunications development and economic growth in China. Telecommun Policy 18:211-5

Ding L, Haynes K (2006) The role of telecommunications infrastructure in regional economic growth in China. Australasian J Reg Stud 12:281-302

Direction des Services Socioculturels et de la Promotion Humaine de la Mairie du Plateau (2009) Rapport sur le context socio-economique en Côte d'Ivoire. Available via Centre international de formation de l'Organisation internationale du Travail. http://recap.itcilo.org/fr/documentation/files-eloise/rapport-surle-contexte-socioeconomique-encote-d-ivoire/view. Accessed 15 Jun 2013

Donner J (2009) Blurring livelihoods and lives: the social uses of mobile phones and socioeconomic development. Innovations 4:91-101

Duflo E, Banerjee A (2011) Poor economics. Public Affairs, Jackson, Mississippi, USA

Eagle N, de Montjoye YA, Bettencourt LMA (2009) Community computing: Comparisons between rural and urban societies using mobile phone data. In: IEEE international conference on computational science and engineering, Vancouver, 29-31, Aug 2009. IEEE in Piscataway, NJ

Eagle N, Macy M, Claxton R (2010) Network diversity and economic development. Science 328:1029-31

Easterley WR (2002) The elusive quest for growth. MIT Press, Cambridge, MA

Forestiera E, Graceb J, Kenny C (2002) Can information and communication technologies be pro-poor? Telecommun Policy 26:623-46

Fujita M, Mori T (1997) Structural stability and evolution of urban systems. Reg Sci Urb Econ 27:399-442

Fujita M, Krugman P, Venables AJ (2001) The spatial economy: cities, regions, and international trade. MIT Press, Cambridge, MA

Goddard JB, Gillespie AE (1986) Advanced telecommunications and regional economic development. Geophys J Roy Astron Soc 152:383-97

Gruber H, Koutroumpis P (2011) Mobile Telecommunications and the Impact on Economic Development. Centre for Economic Policy Research. Econ Policy 26:387-426

Hall P (1998) Cities in civilization. Pantheon, New York

Haltiwanger J, Jarmin RS, Miranda J (2013) Who creates jobs? small versus large versus young. Rev Econ Stat 95:347-61

Hardy AP (1980) The role of the telephone in economic development. Telecommun Policy 4:278-86

Hayek FA (1945) The use of knowledge in society. Am Econ Rev 35:519-30

Heckman JJ (2000) Policies to foster human capital. Res Econ 541:3-56

Hidalgo C, Klinger B, Barabasi A-L, Hausmann R (2007) The product space conditions and the development of nations. Science 317:482-7

Holston J (2008) Insurgent citizenship. Princeton University Press, Princeton, NJ

Hosmana L, Fifeb E, Armeyc LE (2008) Information technology for development. 14:308-27

Hsu WT (2012) Central place theory and city size distribution. Econ J 122:903-32

llahiane H, Sherry J (2008) Joutia: street vendor entrepreneurship and the informal economy of information and communication technologies in Morocco. J North African Stud 13:243-55

International Monetary Fund (2009) Côte d'Ivoire: Poverty Reduction Strategy Paper, IMF Country Report No. 09/156. International Monetary Fund, Washington, D.C, Available via IMF. http://www.imf.org/external/pubs/ft/scr/ 2013/cr13172.pdf. Accessed 15 Jun 2013

Isard W (1975) A simple rationale for gravity model type behavior. Pap Reg Sc 35:25-30

Jacobs J (1970) The economy of cities. Jonathan Cape Ltd., New York

Jensen R (2007) The digital provide: information (Technology), market performance, and welfare in the South Indian Fisheries Sector. Q J Econ 122:879-924

Jones Cl, Romer P (2010) The new Kaldor facts: ideas, institutions, population, and human capital. Am Econ J: Macro 2:224-45

Krings G, Calabrese F, Ratti C, Blondel VD (2009) Urban gravity: a model for inter-city telecommunication flows.J Stat Mech 07:107003

Lall SV (2007) Infrastructure and regional growth, growth dynamics and policy relevance for India. Ann Reg Sci 41:581-99

Lam P-L, Shiu A (2010) Economic growth, telecommunications development and productivity growth of the telecommunications sector: evidence around the world. Telecommun Policy 34:185-99
Lazer D, Pentland A, Adamic L, Aral S, Barabasi A-L, Brewer D, Christakis N, Contractor N, Fowler J, Gutmann M, Jebara T, King G, Macy M, Roy D, Van Alstyne M (2009) Life in the network: the coming age of computational social science. Science $323: 721$

Leontief W (1986) Input-output economics. Oxford University Press, New York

Lobo J, Bettencourt LMA, Strumsky D, West GB (2013) Urban scaling and the production function for cities. PLOS One 8:e58407

Losby JL, Else JF, Kingslow ME, Edgcomb EL, Malm ET, Kao V (2002) Informal economy literature review. Available via Microenterprise Fund for Innovation, Effectiveness, Learning, and Dissemination (FIELD). http://fieldus. org/Projects/pdf/InformalEconomy.pdf. Accessed 15 Jun 2013

Lösch A (1954) The economics of location. Yale University Press, New Haven, CT

Lynch K (1981) Good city form. MIT Press, Cambridge, MA

Miard F (2009) Call for Power? mobile phones as facilitators of political activism'. paper presented at the 50th annual convention of the International Studies Association, New York. http://www.miard.ch/papers/ phonesandpowerll.pdf

Mintzberg H (1994) The fall and rise of strategic planning. Harvard Bus Rev 72:107-14

Mori T, Nishikimi K, Smith TE (2008) The number average size rule: a new empirical relationship between industrial location and city size. J Reg Sci 48:165-211

Nelson RR, Phelps ES (1966) Investment in humans, technological diffusion, and economic growth. Am Econ Rev 56:69-75

Nunan F, Satterthwaite D (2001) The influence of governance on the provision of urban environmental infrastructure and services for low-income groups. Intl Plan Stud 64:409-26

Patel S, Burra S, d'Cruz C (2001) Slum/Shack Dwellers International (SDI) - foundations to treetops. Environ Urban 13:45-59

Robertson C, Sawford K, Daniel SL, Nelson TA, Stephen C (2010) Mobile phonebased infectious disease surveillance system, Sri Lanka. Emerg Infect Dis 16:1524

Röler L-R, Waverman L (2001) Telecommunications infrastructure and economic development: a simultaneous approach. Am Econ Rev 91:909-23

Romer PM (1994) The origins of endogenous growth. J Econ Perspect 8:3-22

Sahooa P, Dashb RK (2009) Infrastructure development and economic growth in India. J Asia Pacific Econ 14:351-65

Sahooa P. Dashb RK (2012) Economic growth in South Asia: role of infrastructure. J Int Trade Econ Devel 21:217-52

Sampson RJ (2012) Great American city: Chicago and the enduring neighborhood effect. University of Chicago Press, Chicago

Sarcevic A, Palen L, White J, Starbird K, Bagdouri M, Anderson K (2012) Beacons of hope in decentralized coordination: learning from on-the-ground medical Twitterers during the 2010 Haiti Earthquake. In: Proceedings of the ACM 2012 conference on computer supported cooperative work. Seattle, 11-15 Feb 2012

Schläpfer M, Bettencourt LMA, Raschke M, Claxton R, Smoreda Z, West GB, Ratti C (2012) The scaling of human interactions with city size. arXiv preprint arXiv:1210.5215

Sen A (1999) Development as freedom. Alfred A Knopf, New York

Shannon CE (1948) A mathematical theory of communication. Bell Syst Tech J 27:379-423

Singh N, Zhou Y, Williams K, Kendall J, Kaushik PD (2013) Bridging the digital divide in rural India lessons from a survey in four states. Rev Mark Integration 5:1-42

Sleuwaegen L, Goedhuys M (2002) Growth of firms in developing countries, evidence from Côte d'Ivoire. J Dev Econ 68:117-35

Ssewanyana JK (2007) ICT access and poverty in Uganda. Int J Comput ICT Res 1:10-9

Starbird K, Palen L (2011) Voluntweeters: Self-organizing by digital volunteers in times of crisis. In: Proceedings of the SIGCHI conference on human factors in computing systems. Vancouver, 7-12 May 2011

Sullivan N (2007) You can hear me now: How microloans and cell phones are connecting the world's poor to the global economy. Jossey-Bass, San Francisco

The Economist Online (2012) The urbanization trap. Available via The Economist Newspaper Limited. http://www.economist.com/blogs/graphicdetail/2012/ 10/daily-chart. Accessed 30 Mar 2013

The World Bank (2009) Information and communications for development 2009: extending reach and increasing impact. The International Bank for Reconstruction and Development/The World Bank, Washington D.C., http:// go.worldbank.org/NATLOH7HVO. Accessed 12 July 2014 
Townsend AM (2001) The internet and the rise of the new network cities, 1969-1999. Env Plann B 28:39-58

United Nations Development Program (UNDP) (2004) Rapport national sur le développement humain en Côte d'Ivoire, cohesion sociale et reconstruction national. Available via United Nations Development Program. http://hdr undp.org/en/content/social-cohesion-and-national-reconstruction. Accessed 15 Jun 2013

Vu KM (2011) ICT as a source of economic growth in the information age: empirical evidence from the 1996-2005 period. Telecommun Policy 35:357-72

Yoneki E (2011) FluPhone study: Virtual disease spread using haggle. In: Proceedings of the 6th ACM workshop on challenged networks. Las Vegas, NV, 19-23 Sept 2011

doi:10.1186/s40551-014-0001-4

Cite this article as: Andris and Bettencourt: Development, information and social connectivity in Côte d'Ivoire. Infrastructure Complexity 2014 1:1.

Submit your manuscript to a SpringerOpen ${ }^{\circ}$ journal and benefit from:

- Convenient online submission

- Rigorous peer review

- Immediate publication on acceptance

- Open access: articles freely available online

- High visibility within the field

- Retaining the copyright to your article

Submit your next manuscript at $>$ springeropen.com 